\title{
Analysis of the Indian National Education Policy 2020 towards Achieving its Objectives
}

\author{
P. S. Aithal ${ }^{1} \&$ Shubhrajyotsna Aithal ${ }^{2}$ \\ ${ }^{1}$ College of Management \& Commerce, Srinivas University, Mangalore - 575 001, India \\ ${ }^{2}$ Faculty, College of Engineering \& Technology, Srinivas University, Mangalore, India \\ E-mail: psaithal@gmail.com
}

Area/Section: Education Management.

Type of the Paper: Research Analysis.

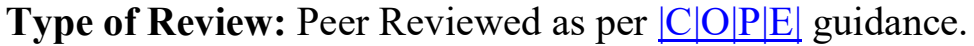

Indexed in: OpenAIRE.

DOI: http://doi.org/10.5281/zenodo.3988767.

Google Scholar Citation: IJMTS.

\section{How to Cite this Paper:}

Aithal, P. S., \& Aithal, Shubhrajyotsna (2020). Analysis of the Indian National Education Policy 2020 towards Achieving its Objectives. International Journal of Management, Technology, and Social Sciences (IJMTS), 5(2), 19-41. DOI: http://doi.org/10.5281/zenodo.3988767.

International Journal of Management, Technology, and Social Sciences (IJMTS)

A Refereed International Journal of Srinivas University, India.

(C) With Authors.

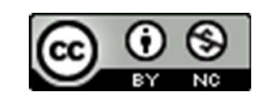

This work is licensed under a Creative Commons Attribution-Non-Commercial 4.0 International License subject to proper citation to the publication source of the work.

Disclaimer: The scholarly papers as reviewed and published by the Srinivas Publications (S.P.), India are the views and opinions of their respective authors and are not the views or opinions of the SP. The SP disclaims of any harm or loss caused due to the published content to any party. 


\title{
Analysis of the Indian National Education Policy 2020 towards Achieving its Objectives
}

\author{
P. S. Aithal ${ }^{1} \&$ Shubhrajyotsna Aithal ${ }^{2}$ \\ ${ }^{1}$ College of Management \& Commerce, Srinivas University, Mangalore - 575 001, India \\ ${ }^{2}$ Faculty, College of Engineering \& Technology, Srinivas University, Mangalore, India \\ E-mail: psaithal@gmail.com
}

\begin{abstract}
Well defined and futuristic education policy is essential for a country at school and college levels due to the reason that education leads to economic and social progress. Different countries adopt different education systems by considering the tradition and culture and adopt different stages during their life cycle at school and college education levels to make it effective. Recently Government of India announced its new Education policy which is based on the recommendations by an expert committee headed by Dr. Kasturirangan, Former chairman of the Indian Space Research Organization (ISRO). This paper highlights on various policies announced in the higher education system and compare them with the currently adopted system. Various innovations and predicted implications of NEP 2020 on the Indian higher education system along with its merits are discussed. Finally, some suggestions are proposed for its effective implementation towards achieving its objectives.
\end{abstract}

Keywords: Higher education, National education policy 2020, NEP-2020, Overview \& analysis, Implementation strategies, Predicted implications, Predicted impediments\& merits.

\section{INTRODUCTION :}

India, being a growing liberal country for educational reforms, currently has about 845 universities and approximately 40,000 higher education institutions (HIEs), reflecting the overall high fragmentation and many small sized HEIs in the country which are affiliated to these universities [1]. It is found that over $40 \%$ of these small sized institutions are running single programme against the expected reform to a multidisciplinary style of higher education which is an essential requirement for the educational reforms in the country for the $21^{\text {st }}$ century [2]. It is also noted that over $20 \%$ of the colleges have annual enrolment less than 100 students making them nonviable to improve the quality of education and only $4 \%$ of colleges enroll more than 3,000 students annually due to regional imbalance as well as the quality of education they offer. Some of the reasons found for the fragmentation of the higher education (HE) system in India are [3]:

- Early streaming of students into different disciplines.

- Lack of access to HE, especially in socio-economically disadvantaged areas which resulted in the current gross enrolment ratio (GER)of $25 \%$ only.

- Lack of teacher and institutional autonomy to make innovations in HE to attract many students.

- Insufficient mechanisms for career management and progression of faculty and institutional leaders.

- The lack of research and innovations at most of the universities and colleges.

- Suboptimal levels of governance and leadership at higher education institutions.

- A corrupted regulatory system allowing fake colleges to thrive while constraining excellent, innovative institutions.

It is predicted that India will be the third largest economy in the world by 2030-2032 with estimated GDP of ten trillion dollars. It is evident that the ten trillion economy will be driven by knowledge resources and not 
by the natural resources of the country. To boost the growth of the Indian education sector, the present government decided to revamp it by introducing a comprehensive National Education Policy 2020. This is in line with the Prime Minister's recent call on leveraging the Fourth Industrial Revolution to take India to new heights. The currently introduced National Education Policy 2020 envisions an India centered education system that contributes directly to transforming our nation sustainably into an equitable and vibrant knowledge society, by providing high quality education to all [4].The first national education policy after independence was announced in the year 1968 and the second national education policy which was improved version of the first was announced in the year 1986.

\section{OBJECTIVES OF THE STUDY :}

The National Education policy 2020 has many initiatives to improve the quality and the broadness of the education system in India. The objectives of this study on National Education Policy 2020 are :

(1) To highlights and overview the policies of the newly accepted higher education system (NEP 2020

(2) To compare National Education Policy 2020 with the currently adopted policy in India

(3) To identify the innovations in new national higher education policy 2020.

(4) To predict the implications of NEP 2020 on the Indian higher education system.

(5) To discuss the merits of Higher Education Policies of NEP 2020.

(6) Suggestions for further improvements for the effective implementation of NEP 2020 to realize its goal.

\section{METHODOLOGY :}

The methodology consists of a conceptual discussion on highlighting the gist of the national educational policy framework, highlighting various sections of the policy of NEP 2020and comparing it with currently adopted education policy. Identifying the innovations made using the focus group discussion method [5-6]. The implications of the policy are analysed using the predictive analysis technique [7-8]. Many suggestions are given based on Focus group analysis.

\section{HIGHLIGHTS OF INDIAN NATIONAL EDUCATION POLICY 2020 :}

\subsection{Highlights of the Stages :}

The National Education Policy 2020 envisions an India centered education system by considering its tradition, culture, values and ethos to contribute directly to transform the country into an equitable, sustainable, and vibrant knowledge society. By drawing inputs from its vast and long historical heritage and considering the contributions from many scholars to the world in diverse fields such as mathematics, astronomy, metallurgy, medical science and surgery, civil engineering and architecture, shipbuilding and navigation, yoga, fine arts, chess, etc., the entire Indian education system is founded and built. The objective of the currently announced NEP 2020 is to provide a multidisciplinary and interdisciplinary liberal education to every aspirant to raise the current gross enrolment ratio (GER) to $50 \%$ by 2035 . The various educational lifecycle stages announced in the policy are listed in table 1 along with their special features [4].

Table 1 : Various educational stages to be implemented as per NEP 2020 [4]

\begin{tabular}{|l|l|l|}
\hline S. No. & $\begin{array}{c}\text { Educational life-cycle } \\
\text { Stage }\end{array}$ & \multicolumn{1}{c|}{ Features } \\
\hline 1 & Foundation Stage & $\begin{array}{l}\text { Five years Foundational Stage provides basic education which is } \\
\text { flexible, multilevel, play-based, activity-based, and discovery-based } \\
\text { learning. Using time tested Indian traditions and cultures, this stage is } \\
\text { continuously improved by research and innovation for the cognitive } \\
\text { and emotional stimulation of children. }\end{array}$ \\
\hline 2 & Preparatory Stage & $\begin{array}{l}\text { Three years Preparatory stage consists of building on the play-, } \\
\text { discovery-, and activity-based learning. In addition to it, this stage } \\
\text { gradually introduces formal classroom learning with textbooks. The }\end{array}$ \\
\hline
\end{tabular}




\begin{tabular}{|c|c|c|}
\hline & & $\begin{array}{l}\text { focus is to expose different subjects to the students and prepare them } \\
\text { to delve deeper into insights. }\end{array}$ \\
\hline 3 & $\begin{array}{l}\text { Middle school } \\
\text { education Stage }\end{array}$ & $\begin{array}{l}\text { Three years of Middle school education focus on more abstract } \\
\text { concepts in each subject like sciences, mathematics, arts, social } \\
\text { sciences, and humanities. Experiential learning is the method to be } \\
\text { adopted in specialised subjects with subject teachers. Students are } \\
\text { exposed to the semester system and yearly two class level } \\
\text { examinations will be conducted. }\end{array}$ \\
\hline 4 & $\begin{array}{l}\text { Secondary education } \\
\text { Stage }\end{array}$ & $\begin{array}{l}\text { Four years of Secondary school education is designed to provide } \\
\text { multidisciplinary subjects including Liberal Arts education. This } \\
\text { stage will be built on the subject-oriented pedagogical and curricular } \\
\text { style with greater depth, greater flexibility, greater critical thinking, } \\
\text { and attention to life aspirations, Students are exposed to the semester } \\
\text { system and will study } 5 \text { to } 6 \text { subjects in each semester. There will be } \\
\text { Board exams at the end of } 10^{\text {th }} \text { and } 12^{\text {th }} \text { standards. }\end{array}$ \\
\hline 5 & $\begin{array}{l}\text { Under-graduation } \\
\text { Education Stage }\end{array}$ & $\begin{array}{l}\text { The Undergraduate degrees in every subject will be of either three- or } \\
\text { four-year duration with multiple exit options including a certificate } \\
\text { after passing first year, a diploma after passing second year, or a } \\
\text { Bachelor 's degree after passing third year. The four years } \\
\text { undergraduate degree programme is preferred with major, minors and } \\
\text { research projects. }\end{array}$ \\
\hline 6 & $\begin{array}{l}\text { Post-graduation } \\
\text { Education Stage }\end{array}$ & $\begin{array}{l}\text { The Master's degree - a one-year for four years bachelor degree } \\
\text { students, a two-year degree for three years bachelor degree students, } \\
\text { and an integrated five-year degree with a focus on high quality } \\
\text { research in the final year. The Masters' degree will consist of a strong } \\
\text { research component to strengthen competence in the professional area } \\
\text { and to prepare students for a research degree. }\end{array}$ \\
\hline 7 & Research Stage & $\begin{array}{l}\text { Research stage consists of pursuing high quality research leading to a } \\
\text { Ph.D. in any core subject, multidisciplinary subject, or } \\
\text { interdisciplinary subject for a minimum period of three to four years } \\
\text { for full-time and part-time study respectively. During Ph.D. they } \\
\text { should undergo 8-credit coursework in teaching/ education/ pedagogy } \\
\text { related to their chosen Ph.D. subject. The earlier one-year MPhil } \\
\text { programme is discontinued. }\end{array}$ \\
\hline 8 & Lifelong learning & $\begin{array}{l}\text { The NEP } 2020 \text { proposes lifelong learning and research to avoid } \\
\text { human beings becoming obsolete in society in terms of knowledge, } \\
\text { skills, and experience to lead a comfortable life. It is believed that } \\
\text { education and research at any stage of life will give further maturity } \\
\text { for satisfaction in life. }\end{array}$ \\
\hline
\end{tabular}

\subsection{Comparison of new NEP 2020 with Existing NEP :}

The 1986 National Education policy focussed on the modernization of the education sector using information technology. More attention was given to restructuring teacher education, early childhood care, women's empowerment, and adult literacy. It also proposed that the autonomy of universities and colleges will improve the quality of education services. But NEP 1986 failed to improve the quality of education in terms of creating graduates with employability skills and failed to generate research output in terms of patents and scholarly publications. To compensate for the failure of previous NEPs, NEP 2020 has proposals of a liberal education to support multidisciplinary and cross-disciplinary education and research in under-graduation and postgraduation levels. Table 2 compares the improvements of some of the features of National Education policy 
2020 with its previous National Education policy 1986.

Table 2 : Comparison of National Education policy 1986 \& National Education policy 2020

\begin{tabular}{|c|c|c|}
\hline $\begin{array}{l}\text { S. } \\
\text { No. }\end{array}$ & NEP 1986 & 20 \\
\hline 1 & $\begin{array}{l}\text { The role of education is the all-round } \\
\text { development of students. }\end{array}$ & $\begin{array}{l}\text { Objective is to provide Multidisciplinary \& } \\
\text { interdisciplinary liberal education. }\end{array}$ \\
\hline 2 & $\begin{array}{l}\text { Common education structure of } 10 \\
(5+3+2)+2+3+2 \text { is followed. }\end{array}$ & $\begin{array}{l}\text { Common education structure of } 5+3+3+4+4+1 \text { is } \\
\text { suggested. }\end{array}$ \\
\hline 3 & $\begin{array}{l}\text { The first preliminary education starts at } 6^{\text {th }} \\
\text { year of a child as Primary school level. }\end{array}$ & $\begin{array}{l}\text { The first preliminary education starts at } 3^{\text {rd }} \text { year of a } \\
\text { child as a Foundation stage. }\end{array}$ \\
\hline 4 & $\begin{array}{l}\text { Two years higher secondary level and two } \\
\text { years pre-university levels were separately } \\
\text { considered and both had board exams. }\end{array}$ & $\begin{array}{l}\text { Four years Secondary education stage is designated } \\
\text { by clubbing Two years higher secondary level and } \\
\text { two years pre-university levels. Exams are } \\
\text { suggested at the school level except for Board level } \\
\text { exams at } 10^{\text {th }} \text { and } 12^{\text {th }} \text {. }\end{array}$ \\
\hline 5 & $\begin{array}{l}\text { Two years of higher secondary level, } \\
\text { students choose specialization areas and } \\
\text { subjects like Science subjects or Commerce } \\
\text { subjects or Arts subjects }\end{array}$ & $\begin{array}{l}\text { Four years Secondary education stage contains } \\
\text { common subjects and elective subjects. Choice is } \\
\text { based on liberal education policy. }\end{array}$ \\
\hline 6 & $\begin{array}{l}\text { All undergraduate and postgraduate } \\
\text { admissions are based on the entrance exam } \\
\text { conducted at the college level or state level } \\
\text { except NITs \& Medical Colleges. }\end{array}$ & $\begin{array}{l}\text { All undergraduate and postgraduate admissions of } \\
\text { public HEIs are based on National Testing Agency } \\
\text { (NTA) scores conducted by the national level. }\end{array}$ \\
\hline 7 & ate programmes are for three to & $\begin{array}{l}\text { Undergraduate programmes are of four years with a } \\
\text { provision to exit after one year with a diploma, after } \\
\text { two years with an advanced diploma, after three } \\
\text { years with a pass degree, and after four years with } \\
\text { project based degree. }\end{array}$ \\
\hline 8 & with & $\begin{array}{l}\text { Postgraduate education is of one to two years with } \\
\text { more specialization \& research focus. }\end{array}$ \\
\hline 9 & $\begin{array}{l}\text { ges in HEIs are affiliated } \\
\mathrm{s} \text { and had no autonomy in } \\
\text { aluation. }\end{array}$ & $\begin{array}{l}\text { All HEIs including colleges are autonomous and } \\
\text { there will be no affiliated colleges to state } \\
\text { universities and autonomy in deciding curriculum } \\
\text { and evaluation. }\end{array}$ \\
\hline 10 & $\begin{array}{l}\text { Examination is independent of teaching. All } \\
\text { examination and evaluation is affiliating } \\
\text { university controlled. There is a little role of } \\
\text { teaching faculty members in evaluating the } \\
\text { students directly. }\end{array}$ & $\begin{array}{l}\text { Examination is a part of a continuous evaluation } \\
\text { system. Faculty members who are teaching a subject } \\
\text { are responsible for evaluation and examinations are } \\
\text { departmental affairs. }\end{array}$ \\
\hline 11 & Teaching-learning method mainly focuses & $\begin{array}{l}\text { ing method mainly focuses on } \\
\text { ing, fieldwork, and research projects. }\end{array}$ \\
\hline 12 & $\begin{array}{l}\text { In the higher education system, the expected } \\
\text { student-faculty ratio is } 20: 1 .\end{array}$ & $\begin{array}{l}\text { In higher education system, the expected student- } \\
\text { faculty ratio is } 30: 1 \text {. }\end{array}$ \\
\hline 13 & $\begin{array}{l}\text { In HEIs faculty members are considered as } \\
\text { facilitators of educating students to make } \\
\text { them competent. }\end{array}$ & $\begin{array}{l}\text { In HEIs faculty members are considered as } \\
\text { collaborators and guide of educating students to } \\
\text { make them as innovators \& creative thinkers. }\end{array}$ \\
\hline 14 & $\begin{array}{l}\text { Students have the freedom to choose } \\
\text { subjects across their area of study. }\end{array}$ & $\begin{array}{l}\text { Students have the freedom to choose subjects } \\
\text { outside and across their area of study. }\end{array}$ \\
\hline
\end{tabular}




\begin{tabular}{|c|c|c|}
\hline 15 & $\begin{array}{l}\text { A one year research degree leading to } \\
\text { M.Phil. in any subject is offered to provide } \\
\text { preliminary experience to do research. }\end{array}$ & $\begin{array}{l}\text { A one year research degree leading to M.Phil. in any } \\
\text { subject is discontinued due to the reason that } \\
\text { students are exposed to preliminary research in their } \\
\text { undergraduate and post-graduate courses. }\end{array}$ \\
\hline 16 & $\begin{array}{l}\text { Pass in NET/SLET along with respective } \\
\text { Masters degrees as an essential qualification } \\
\text { to become an Assistant professor in any } \\
\text { three types of HEIs. }\end{array}$ & $\begin{array}{l}\text { Ph.D. degree is compulsory along with pass in } \\
\text { NET/SLET as an essential qualification to become } \\
\text { an Assistant professor in any three types of HEIs. }\end{array}$ \\
\hline 17 & $\begin{array}{l}\text { The support of research funds through UGC } \\
\text { or any other agencies is mainly for } \\
\text { Universities than Colleges. }\end{array}$ & $\begin{array}{l}\text { The support of research funds through the National } \\
\text { Research Foundation and any other agencies will be } \\
\text { equally distributed to all three types of HEIs based } \\
\text { on a fair evaluation of the research proposal. }\end{array}$ \\
\hline 18 & $\begin{array}{l}\text { HEIs accreditation is compulsory for } \\
\text { availing funds and government facilities } \\
\text { only. }\end{array}$ & $\begin{array}{l}\text { HEIs accreditation is compulsory for functioning } \\
\text { and offering the degree. Compulsory accreditation } \\
\text { is required once for every five years for continuous } \\
\text { operation. }\end{array}$ \\
\hline 19 & The graded accreditation model is followed. & $\begin{array}{l}\text { Binary accreditation model will be followed which } \\
\text { is yes or no system instead of various grades for } \\
\text { institution. }\end{array}$ \\
\hline 20 & $\begin{array}{l}\text { Faculty performance \& accountability is } \\
\text { linked to promotion but not linked to } \\
\text { compensation. }\end{array}$ & $\begin{array}{l}\text { Faculty performance } \& \text { accountability is linked to } \\
\text { promotion and compensation. }\end{array}$ \\
\hline 21 & Choice based credit system. & $\begin{array}{l}\text { Liberal education based on STEAM \& Competency } \\
\text { based credit system. }\end{array}$ \\
\hline 22 & $\begin{array}{l}\text { Only accredited \& permitted Universities } \\
\text { are allowed to offer Online Distance } \\
\text { Learning (ODL) education. }\end{array}$ & $\begin{array}{l}\text { All } 3 \text { types of HEIs which are accredited to offer } \\
\text { ODL are permitted to offer ODL. }\end{array}$ \\
\hline 23 & $\begin{array}{l}\text { Social engagement for every student as a } \\
\text { part of the programme curriculum is } \\
\text { optional. }\end{array}$ & $\begin{array}{l}\text { Social engagement for each student is compulsory } \\
\text { and should be equal to at least one full semester } \\
\text { across the entire duration of the programme. }\end{array}$ \\
\hline 24 & $\begin{array}{l}\text { Four years of Bachelor degree holders are } \\
\text { not eligible for direct admission to Ph.D. } \\
\text { programme unless they acquire Masters } \\
\text { degree. }\end{array}$ & $\begin{array}{l}\text { Four years of Bachelor degree holders with proven } \\
\text { research performance during the fourth year can } \\
\text { directly admit to Ph.D. programme without Masters } \\
\text { degree in both types of HEIs. }\end{array}$ \\
\hline 25 & $\begin{array}{l}\text { Lateral entry is offered in some } \\
\text { programmes. But no Multiple entries and } \\
\text { Multiple exit facilities are available in under } \\
\text { graduation including medical and } \\
\text { paramedical courses. }\end{array}$ & $\begin{array}{l}\text { Multiple entries and Multiple exit facilities are } \\
\text { available in under graduation including medical and } \\
\text { paramedical courses. }\end{array}$ \\
\hline 26 & $\begin{array}{l}\text { Undergraduate programmes of } 3 \text { years to } 4 \\
\text { years depending on the type of the } \\
\text { programme. }\end{array}$ & $\begin{array}{l}\text { All undergraduate programmes are of } 4 \text { years with, } \\
\text { in some cases, exit at } 3 \text { years is possible with a } \\
\text { degree certificate. }\end{array}$ \\
\hline 27 & $\begin{array}{l}\text { Currently, teacher's education comprises of } \\
\text { two years B.Ed. programme after } \\
\text { graduation. So secondary school teachers } \\
\text { have to spend } 5 \text { years after their higher } \\
\text { secondary education to teach at higher the } \\
\text { secondary level. }\end{array}$ & $\begin{array}{l}\text { The proposed teacher's education comprises of four } \\
\text { years integrated B.Ed. This degree is a compulsory } \\
\text { requirement to become faculty in School education } \\
\text { Stages. }\end{array}$ \\
\hline 28 & Suggestion for improving physical library & Suggestion \\
\hline
\end{tabular}




\begin{tabular}{|l|l|l|}
\hline facility including books \& journals & $\begin{array}{l}\text { memberships including online books \&online } \\
\text { journals. }\end{array}$ \\
\hline 29 & $\begin{array}{l}\text { Both single discipline and multidiscipline } \\
\text { colleges are promoted. }\end{array}$ & $\begin{array}{l}\text { Only multidisciplinary colleges and universities are } \\
\text { promoted. All single discipline colleges have to } \\
\text { convert themselves autonomous multidisciplinary } \\
\text { colleges or will be closed and converted into } \\
\text { monuments or public libraries. }\end{array}$ \\
\hline 31 & $\begin{array}{l}\text { No foreign universities are allowed to } \\
\text { function directly in India } \\
\text { The coursework of Ph.D. programme } \\
\text { core subject related study methodology and }\end{array}$ & $\begin{array}{l}\text { About 100 top ranked foreign universities will be } \\
\text { allowed to function in India to compete with Indian } \\
\text { universities }\end{array}$ \\
\hline 32 & $\begin{array}{l}\text { Nhe coursework of Ph.D. programme comprises of } \\
\text { research methodology, Teaching \& curriculum } \\
\text { development aspects along with core subject related } \\
\text { study } \\
\text { research for Unives andic and and funding }\end{array}$ \\
\hline $\begin{array}{l}\text { National Research Foundation (NRF) will be } \\
\text { formed to fund for competitive and innovative } \\
\text { research proposals of all types and across all } \\
\text { disciplines. }\end{array}$ \\
\hline
\end{tabular}

\section{HIGHLIGHT OF POLICIES OF NEP 2020 FOR HE SYSTEM :}

\subsection{Higher Education :}

(1) HE monitoring and controlling institutions like UGC, AICTE, MCI, DCI, INC, etc will be merged with the Higher Education Commission of India (HECI) as a single regulator for HEI.

(2) The current Accreditation Institutions like NAAC and NAB will be replaced by a robust National Accreditation Council (NAC).

(3) Establishment of a National Research Foundation (NRF) to fund research in universities and colleges.

(4) Consolidation of existing fragmented HEIs into two types of Multidisciplinary Universities (MU) and Multidisciplinary Autonomous Colleges (AC) with the campus having more than 3,000 students. The Timeline to become multi-disciplinary is by 2030 and to have 3,000 and more students by 2040 .

(5) Multidisciplinary Universities will be of two types as (1) Research-intensive Universities, and (2) Teaching-intensive Universities.

(6) Every existing College will develop into either degree granting autonomous College or migrated into a Constituent College of University and becomes fully a part of the University.

(7) The Gross Enrolment Ratio in HE including Vocational education will increase from current $26.3 \%$ (2018) to $50 \%$ by 2035 .

(8) HEIs which deliver the highest quality will get more incentives from the Government.

(9) All existing affiliated Colleges will eventually grow autonomous degree-granting colleges with the mentoring support of affiliated University by improving and securing the prescribed accreditation level.

(10) The various nomenclatures used currently such as deemed to be university, affiliating university, central university, affiliating technical university, unitary university, etc will be replaced by 'University' after fulfilling the required criteria as per norms.

(11) Research will be included in UG, PG, level and have a holistic and multidisciplinary education approach.

(12) Pedagogy in HEIs will focus on communication, presentation, discussion, debate, research, analysis, and interdisciplinary thinking.

(13) An Academic Bank of Credit (ABC) will be established which would digitally store the academic credits of all registered candidates earned from various recognized HEIs (SWAYAM \& ODL mode) that can be 
taken into account while awarding degrees by the college or university.

(14) Four years Bachelor degree with multiple exit options, one to two years Master's degree based on the number of years spent in Bachelor degree as four or three respectively, and option to do Ph.D. for four years Bachelor degree with research are possible.

(15) Two years Master degree with full research in the second year, One year Master degree for four years Bachelor degree holders, and Five years integrated Bachelor/Master degree.

(16) All HEIs will focus on research and innovation by setting up (1) Start-up incubation centres, (2) Technology development centres, (3) Centres in frontier areas of research, (4) Centre for Industry-academic linkage, and (5) Interdisciplinary Research Centres including humanities and social sciences research.

(17) Student Centred teaching \& learning process instead of Teacher centred teaching model.

(18) Choice Based Credit System is revised by an innovative and flexible Competency Based Credit System.

(19) Examination system will change from high-stakes examinations (Semester End system) towards a more continuous and comprehensive evaluation examination system.

(20) All HEIs will have professional academic and career counselling centres with counsellors available to all students to ensure physical, psychological and emotional well-being.

(21) All HEIs will develop, support, and fund for topic-centred clubs and activities organized by students with the help of faculty and other experts as needed, in the area of science, mathematics, poetry, language, literature, debate, music, sports, etc.

(22) Encouragement for Online Distance Learning (ODL) courses as a part of degree programmes to include the credit system.

(23) The Degree programmes may contain in-class teaching, Online teaching components, and ODL components with 40:30:30 ratio model to achieve a global standard of quality.

(24) HE quality will be improved to global quality level to attract more international students and the credits acquired in foreign universities will be counted for the award of a degree.

(25) National Scholarship Portal will be strengthened and expanded to help the financial needs of merit-based students. Private HEIs will be encouraged to offer larger numbers of free ships and scholarships to their students.

\subsection{Teachers Education :}

(26) All stand-alone Teachers Education Institutions should convert themselves as Multi-disciplinary HETs by 2030 to offer only four years integrated B.Ed. programme.

(27) All schools of foundation, preparatory, middle, and secondary level should appoint 4-years integrated B.Ed. degree holders as teachers with dual major specialization (Education \& Subject).

(28) Till 2030, there will be two years B.Ed. programme for 3 years UG and one-year B.Ed. for four years UG and those who have Master's degree in other subjects.

(29) M.Ed. will be one year with research focus. The faculty profile in Departments of Education will be diverse with Ph.D.'s in different areas.

(30) All interested senior or retired faculty will be utilized short or long term for guiding, mentoring, or professional support for research/training/innovation. A separate National Mission for Mentoring will be established.

\subsection{Professional Education :}

(31) All stand-alone professional education institutions in any field shall aim to become multidisciplinary institutions offering holistic and multidisciplinary education by 2030 .

(32) HEIs will be encouraged to prepare professionals in agriculture and veterinary sciences through programmes integrated with general education. HEIs offering agricultural education must focus on the local community and involvement in setting up Agricultural Technology Parks in the region to promote technology incubation and dissemination.

(33) Universities/institutions offering law education must prefer to offer bilingual education for future lawyers and judges - in English and State language.

(34) Healthcare education system must be integrated in such a way that all students of allopathic medical 
education must have a basic understanding of Ayurveda, Yoga and Naturopathy, Unani, Siddha, and Homeopathy (AYUSH), and vice versa. Greater emphasis should be given in all forms of healthcare education to preventive healthcare and community medicine.

(35) Technical education should be offered within multidisciplinary education institutions and should focus on opportunities to engage deeply with other disciplines. The focus should be on offering Artificial Intelligence (AI), 3-D machining, big data analysis, and machine learning, in addition to genomic studies, biotechnology, nanotechnology, neuroscience, with applications to health, environment, and sustainable living.

\subsection{Private Institutions :}

(36) All private universities are eligible for graded autonomy based on their accreditation status.

(37) All private universities / autonomous colleges have to maintain an openness in their financial dealings and the BoG is responsible for any irregularities in the accounting system. BoG should contain eminent people well reputed in their professional area to guide the speedy development of the HEIs.

(38) All HEIs have autonomy in deciding their fees structure and surplus if any should be reinvested in the expansion projects with a transparent accounting system.

(39) All private HEIs should offer 20\% free-ship and 30\% scholarship in the course fee for meritorious students in every course which they offer during a given academic year and this should be checked and confirmed by the accreditation process.

(40) National Research Foundation will treat all private HEIs in par with public HEIs for granting research finds which is only based on the merit of the proposals.

\section{INNOVATIONS IN NEP 2020 :}

(1) 100 top Indian Universities will be encouraged to operate in foreign countries.

(2) 100 top Foreign Universities will be allowed and facilitated to operate in India

(3) Every classroom shall have access to the latest educational technology that enables better learning experiences.

(4) Faculty Stability will be provided in an appointed institution with generally no transfer to other institutions.

(5) Faculty members get curriculum and pedagogy freedom within an approved framework.

(6) Based on academic and research performance, faculty incentives \&accountability will be fixed.

(7) Faculty fast-track promotion system for high impact research contributions will be offered.

(8) A multiple parameter-based API policy with peers \& students' feedback, innovations in teaching \& pedagogy, professional development activities, Quality and impact research, contribution to an institution in terms of admission, and social community contribution will be in place.

(9) The API policy will clearly be defined in the Institutional development plan.

(10) Focus on achieving sustainable Education Development Goal (SEDG) \& GER of 50\% by 2035.

(11) All Ph.D. registered students should take one subject related to teaching/curriculum development and accept teaching Assistantship for enhancing teaching skills.

(12) All students should be encouraged to take SWAYAM online courses at least two courses per semester.

(13) Strengthening Vocational education (VE) to reach at least $50 \%$ of the student population. HEIs should plan how VE can be offered to all the students.

(14) Plan to give B.Voc. as dual degree programme in ODL (Online Distance Learning) mode or 2 hours evening programme through Skill labs \& partnership with industry \& NGOs.

(15) Currently, research \& innovation investment in India is of $0.69 \%$ of GDP against a global average of 3\% of GDP.

(16) Inclusion of research and internships in the undergraduate curriculum as a very essential component.

(17) Four functions of (1) regulation (NHERC), (2) accreditation (NAC), (3) funding/ grants (HEGC), and

(4) academic standard setting (GEC) are controlled by an umbrella institution, the Higher Education Commission of India (HECI). 
(18) GEC decides the $21^{\text {st }}$ century skills to be learned by students.

(19) A faceless and transparent regulatory intervention will be designed using technology to monitor quality in higher education. Strict compliance measures with stringent action, including penalties for false disclosure of mandated information will be taken to ensure the basic minimum norms and standards.

(20) Empower private HEIs to decide fees for their programmes independently, though within the laid-out norms.

(21) Information Communication and Computation Technology (ICCT) \& Nontechnology (NT) will be introduced at undergraduate education to increase the employability of youths.

(22) Dual degrees in Education \& Sanskrit (Dual degrees in 4 years Degree programs), for example, BCA \& BA in Language.

(23) AI Research Centres, Nanotechnology Research centres get support from NRF.

(24) Creation of Virtual Labs along with SWAYAM and Diksha to support MOOC education.

(25) Annual education expenditure of India has to increase from the current $4.43 \%$ of GDP to $6 \%$ of GDP.

(26) HEIs shall also move away from high-stakes examinations towards more continuous and comprehensive evaluation (weightage for internal continuous evaluation and Semester end examination will be 50:50).

(27) Choice based Credit system will be improved and Competency based credit system is going to be adopted.

(28) Focus on effective self-governance and outstanding merit-based leadership appointment and a Board of Governors (BOG) of highly qualified, competent, and dedicated individuals have proven capabilities and a strong sense of commitment to the institution. BOG shall be responsible and accountable to stakeholder's through transparent self-disclosures of all relevant records.

(29) Focus is on the building of digital infrastructure, digital content, and capacity building to keep pace with Tech-generation expectations.

(30) Other innovations like stress on networking with industries and other HEIs for research and collaborations, focus on creating IPR, and improving stakeholders perception are also suggested.

\section{IMPLICATIONS OF NEP 2020 ON INDIAN HIGHER EDUCATION SYSTEM :}

(1) Only qualified role-models have the opportunity to elevate to the top to decision making role: Higher Education policy-making decisions and implementation of such policies may go out of bureaucrats and fake educationists who are enjoying top decision-making positions like Chairman's of UGC, AICTE, MCI, DCI, and Vice-Chancellors of Various Universities. For example, in present HE system in India a person without a single scholarly publication can become Vice-Chancellor of Public Sector Universities and can elevate to various higher positions and even become the chairman of UGC. Similarly, a person without a single patent can become Director of Technical Institutions, and eventually can become the Chairman of AICTE. A person without a single IPR like scholarly publication or patent can reach decision making authority at Higher Education Divisions including the Association of Indian Universities.

(2) Cleaning of Higher Education Bureaucratic system :

Merit-based appointments of Institutional leaders in Research \& Innovations. Unlike the present system, professors without at least five first author scholarly publications or patents during the last five years will not become institutional leaders like Directors, Vice-Chancellors, etc.

(3) Transformation of Single discipline Colleges into a multi-disciplinary autonomous degree-awarding Colleges :

This will again help to decrease corruption and lobbies in Colleges. Many colleges are unable to chart their own courses, controlled as they are by rigid bureaucratic norms of the affiliating University. All this deeply undermines the principle of local governance and the local pursuit of innovation and excellence. This must be addressed with urgency. This also develops more responsible leaders to work in HE administration along with research so that they can make better innovations in imparting higher educational services.

(4) Focus on Research \& Innovation at UG \& PG levels :

This allows students and faculty members to think creatively with confidence to propose and do new things 
leading to novelty.

(5) Highly educated Board of Governors (BoG) to avoid misuse of power by Individuals :

Every autonomous institution is expected to for a BOG having highly qualified, competent, and dedicated individuals who have proven capabilities and a strong sense of commitment to the institution.

(6) The Responsibility of maintaining Quality lies with the Board of Governors :

The BoG shall be responsible and accountable for the outcomes of the HEI to the stakeholders through transparent disclosures of relevant records. BOG has to meet all regulatory guidelines mandated by the National Higher Education Regulatory Authority (NHERA).

(7) Single Regulator for entire HEIs :

National Higher Education Regulatory Authority (NHERA) a single HEIs regulator setup leads to effective regulation of financial probity of HEIs, governance, open disclosure of financials, faculty/staff, courses, and educational qualities.

(8) Elimination of Commercialization of Education :

HEIs both public and private should ensure that they are not for profit and if there is any surplus, it should be re-invested in the institutional development under the supervision of BoG members to eliminate the comultiplication of education.

(9) Responsibility of Private HEIs towards Educational Philanthropy :

Though private HEIs can set their fees independently, by offering at least $20 \%$ free-ship and $30 \%$ scholarships. This model allows to recover reasonably their cost while discharging their social obligations.

(10) Private Universities will overtake Public Universities due to offered $20 \%$ free-ship :

Bright and intelligent students irrespective of their economic status, religion, gender, will get the opportunity to study in private HEIs free of cost due to $20 \%$ free-ship and $30 \%$ scholarship leading to mobilization of intelligent and self-motivated students to Private institutions leading to overcrowding of meritorious students in private Universities.

(11) Transformation of Public/Government Colleges :

Two possible transformation processes: (a) The affiliated public/government colleges can eventually become multi-disciplinary and expand their capacity to admit annually 3,000 or more students and become autonomous colleges (AC). (b) Small colleges with less resources and student feeding areas will convert itself as a constituent college of the affiliating university and get mentorship and all other kinds of support to offer quality education as depicted in figure 1 .

(12) Transformation of Private Colleges :

Three possible of Transformation: (a) The private sector colleges can eventually expand in terms of their resources and quality of education and reaches a predefined accreditation status to become Autonomous Degree giving college,(b) Some small colleges with one or two disciplines and have no scope of expansion to admit 3,000 or more students will join with similar (same management or same religion) colleges in that region and may become a group of colleges or a cluster and transform themselves into a degree giving Autonomous College, (c) The private colleges which cannot form cluster or part of a group and fail to reach the pre-defined accreditation status will eventually close down their operation as depicted in figure 1. 


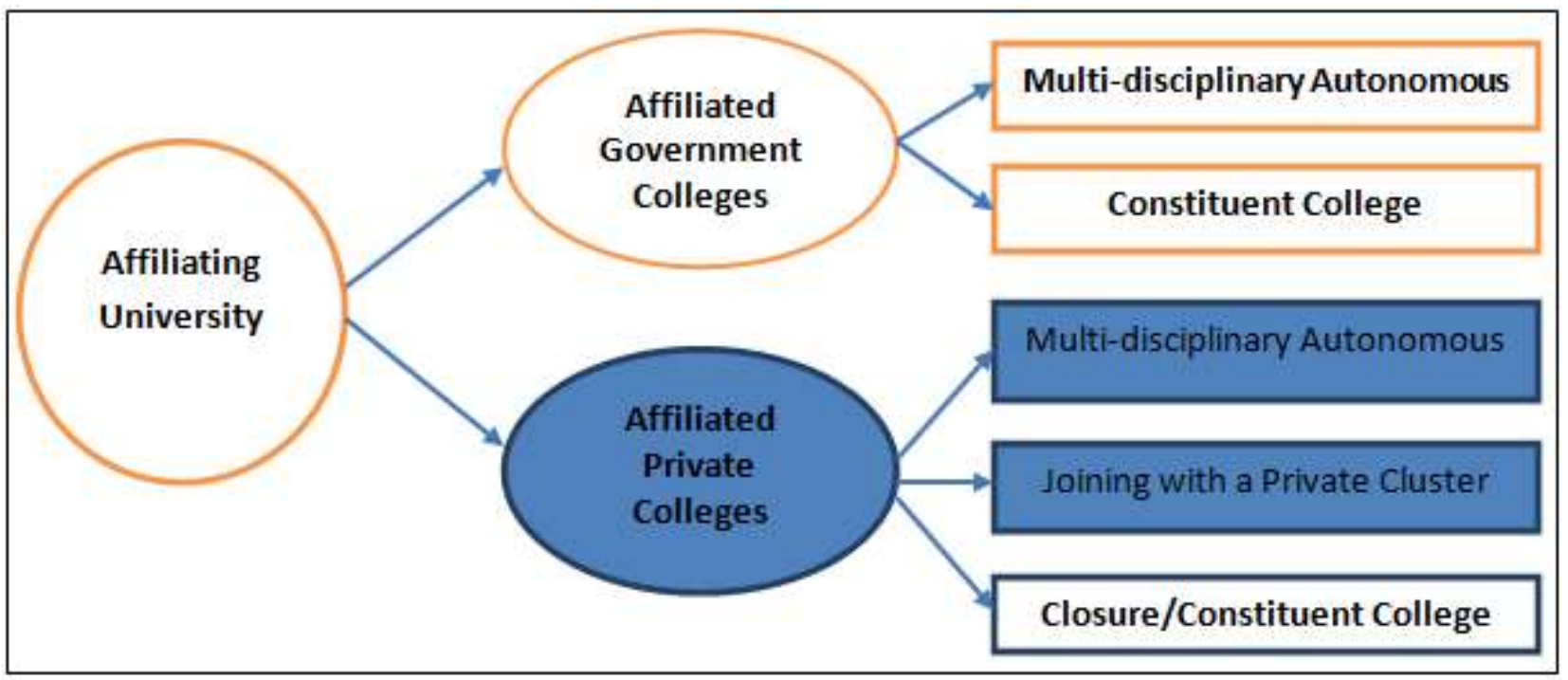

Fig. 1 : Fate of Affiliated Colleges while implementing NEP 2020

\section{IMPEDIMENTSTO REALIZE NEP 2019 PROPOSAL FROM ITS STAKEHOLDERS POINT OF VIEW BASED ON PREDICTIVE ANALYSIS :}

(1) Conversion of affiliated colleges into Autonomous Colleges :

There are many affiliated colleges to public universities which have one or two courses, a small piece of land without enough physical infrastructure (like single building colleges), less than 300 annual admissions, etc. Such colleges cannot- expand their operations to become multi-disciplinary colleges and hence cannot transform themselves into autonomous colleges. Even though the UGC has made it mandatory to have a minimum of 5 acres of land to give and continue affiliation to the colleges, many universities have not strictly followed such conditions. All such government owned colleges can be converted into constituent colleges but privately owner small colleges will be either close their operation or shift to a bigger land with an acceptable level of physical infrastructure.

(2) Transforming Undergraduate and Postgraduate courses into Research based Courses :

To transform current UG and PG courses with information oriented into research oriented is a cumbersome process. For this, first, faculty members of HEIs should develop research skills,

the HEIs should develop research infrastructure, and students should be prepared as independent thinkers to create new knowledge or new analysis of existing information. Changing the mindset of all stakeholders takes time and effort from HEI administrators. Preparing the faculty members for implementing researchoriented curriculum is the first step for which research experienced faculty appointments is crucial. The minimum qualification for faculty appointments in HEIs should be a quality Ph.D. with at least 5 IPR in the form of either scholarly publications or patents.

(3) Maintaining quality \& accountability in Public/Government Universities \& Colleges :

Many currently available faculty members and administrative leaders in public universities are below average due to the fact of non-compliance of merit-based appointments and promotions. The National Education Policy stress on merit-based appointments and promotion in all levels of HE system which is difficult to follow in countries like India. In such a scenario, maintaining quality and accountability is difficult in public sector HEIs.

(4) Merit-based appointment \& Promotion is a nightmare:

In the name of social justice, the country government allows to appoint persons for teaching, research, and administrative positions without the required merits. For example, persons without scholarly publications during last 10 years can become chairman of UGC which is a highest policy making body in HE system of the country, a person without single patent can become chairman of AICTE, and people without single 
scholarly publication/patent during last 5 years can become Vice Chancellors of universities and members of various HE policy committees. With such a situation, how National Education Policy 2020 with stress to merit based appointment $\&$ promotion can be successful to realize its goal ?

(5) Lobbies at Decision making Appointments:

Though, through implementing National Education policy 2020, the central government dreaming that it can transform the Indian education system to a sophisticated and progressive system for economic and social growth, the present corrupt system will continue due to strong control of corrupt individuals at all levels of current HE system. Such influence and favouritism create lobbies at appointments of top decision makers of higher education leading to the promotion of further continuation of a corrupt system. Due to political reasons, it is difficult to remove such lobbies in appointments and hence quality in the higher education system in India.

\section{(6) Influences \& Lobbies in the Accreditation Process :}

Accreditation is the primary mechanism to regulate the quality and monitor the functions of HEIs through a meta-accrediting body called the National Accreditation Council (NAC). The accreditation process checks the quality, self-governance, and autonomy against a standard benchmark and awards graded accreditation status to use enhanced autonomy and findings to grow further. Since accreditation status is an important requirement for, HE organizations, influence, lobbies related corruptions will be possible. By making the criteria and parameters in such a way that only tangible matric systems should be followed to avoid illegal practices in the accreditation process.

(7) Inequality and lobbies in granting Research Funding without proper accountability :

All research funding will be granted and regulated by the National Research Foundation. There should be a proper monitoring system to avoid injustice to many genuine researchers with novel ideas due to partiality in granting funds. A proper monitory system to curb the lobbies and influences by many organizations. Also, the granted research project funds should be utilized fully with the expected outcome and the expenditures should be made open to the public to avoid misuse.

(8) Decreasing wastage of tax paid money in HEIs in the name of quality :

In the name of quality, HE \& Research Institutions will import research facilities that fail to utilize optimally. Many imported research instruments are not utilized properly and multiplicated in many universities. NRF should start many central common research facilities installed in four regions of the country. Currently, many costly research equipment in many universities and research laboratories are not functioning due to lack of maintenance. Through sincere efforts on formulating policies, NRF agency should focus on decreasing the wastage of money in the name of research and quality. Higher education institutions including universities should stop the waste of money collected from students or taxpayers to subscribe to journals and books from international agencies independently. Instead, they should subscribe to them through Integrated National Digital Library as a common facility for the entire country.

\section{MERITS OF HIGHER EDUCATION POLICIES IN NEP-2020 :}

\section{(1) Student Centric Model :}

The current teacher centric model where the teachers decide the subjects, curriculum, evaluation, etc will be replaced by student centric model where student gats right to decide the subject he has to study from the institution, SWYAM MOOC, and from ODL and he can appear for competency based evaluation in his own pace. Thus, the higher education section of NEP-2020 replaces teacher centric education system to student centric system [9-19].

(2) Competency based Continuous Evaluation System :

As against choice-based credit system, competency-based credit system has advantages of evaluating skill sets of a student along with knowledge and experience. Competency leads to confidence and objective of higher education system irrespective of subjects and areas of study is building confidence to identify new challenges and converting them into opportunities to solve problems in the society [20-25].

(3) Research \& Innovation Focused : 
The objective of higher education is to create new knowledge or a new interpretation of existing knowledge through systematic analysis. This will solve all problems of the society optimally. Involving research and innovations as a major component of higher education creates new intellectual property to throw light into new innovative solutions. The higher education policies of NEP-2020 transforms the HE system from information centric to new knowledge and innovation centric [26-32].

(4) Improved STEM model of HE Curriculum:

To generalize higher education for all-round progress of students, it is scientifically proved that they should be exposed to art \& design thinking to improve their creativity in solving problems along with science, technology, engineering, and mathematics. This new model called STEAM is considered as better than STEM model in higher education at a bachelor's degree level [33-39]. STEAM with experimental learning and research based internship is the objective higher education section of NEP-2020.

(5) Faculty Productivity based on Research Output :

Research is an integral part of the higher education system. The faculty members who are guiding quality research should have research motives and experience so that they can be role models for their students. The new education policy focus on merit-based promotions which depend on faculty members annual performance indicator score with major portion depends on their performance in research and publications or patent to contribute to the IPR of the organization and hence of the country. Thus, the accountability of every faculty member in higher education system depends on their research productivity for a given time period [40-48].

(6) Autonomy at all Levels :

Higher education institutions which have the autonomy to do innovations in deciding the courses, curriculum, pedagogy, examination and evaluation could able to improve the quality of educations offered by them. In university affiliation system, affiliated institutions do not have any autonomy in teaching-learning and evaluation systems thereby the quality and motivation of both students and faculty members get affected. Autonomy at education (teaching -learning processes), examination and evaluation, administration including financial decisions are essential for a progress oriented system [49-52].

(7) Merit based Student admissions, Faculty Selection \& Promotion :

NEP 2020 stresses on the importance of student admission based on merit by giving importance to social justice. It also comments that the quality of higher education and research can be improved only if all faculty selections and promotions are merit based. All kinds of reservations and lobbies should be curbed at individual institution level by means of appointing highly qualified and proven leaders as members of the Board of Governors. It also stresses that merit-based appointments are essential at all policy formulating and regulating levels of HE Councils [53-56].

(8) Education Leaders should be Role-Models:

Self-contribution to research and innovation is important to education leaders. New researchers get inspiration by seeing the contribution of leaders to perform better. HEIs should cultivate role models in this sector who should be super performers to IPR of the organization so that the organization can prove that higher contribution is possible. Professors who hold administrative positions are also expected to research and publication field during their leisure period to be role models to young researchers. It has been observed that many professors when elevating to administrative positions forget their responsibility of research and publications and do only lobbies and influences to elevate further. Since NEP-2020 suggest merit-based appointments and promotions, only role-models get further growth opportunities [57-61]

(9) Integrated Controlling \& Monitoring System :

As per NEP-2020, the first 10 years from 2021 to 2030 is the implementation period and the next 10 years

from 2030 to 2040 is the operational period. The implementation process is divided into seven stages [4]:

(1) Implementation of spirit and intent of the policy

(2) Implementation of policy initiatives in a phased manner

(3) Prioritization and sequencing of policy points

(4) Comprehensive full-fledged implementation to achieve the desired objectives 
(5) Collaborative planning, monitoring, and implementation by both Centre and States

(6) Timely supply of required resources by both Centre and States

(7) Careful analysis and review of multiple linkages to ensure effective dovetailing of all initiatives

Effective use of technology to monitor and control each stage is essential for the expected progress of implementation.

(10) Boost to Online training :

Use of Information Communication and Computation Technologies (ICCT) including Education technology, Internet technology, Artificial intelligence, Virtual reality, etc are very essential in effective implementation of education in the $21^{\text {st }}$ century. The latest technologies help planning, design offering effective online education to realize the characteristics of the ideal education system and also to enhance GER. It is expected that during the $21^{\text {st }}$ century, due to improved tech generations, technology driven education is going to replace classroom based education and the policies of NEP-2020 laying the foundation for it but also supports classroom based education system by adding more research components in it [62-69].

(11) Control of Quality through Biennial Accreditation Process :

Currently, the National Assessment and Accreditation Council monitors the quality of education and awards the graded accreditations to HEIs. This accreditation timeframe is five years. As a result, HEIs are not continuously monitored for their accreditation status. Instead, to make accreditation status more serious and effective for continuous improvement, NEP-2020 has simplified it and made it mandatory as a biennial accreditation process. This model of accreditation holds tight control on higher educational institutions to actually work for quality and performance [70-73].

(12) Boost of GER through Autonomy to Private Sector :

One of the major goals of the United Nations Sustainable Development Goals is quality education to everyone. This can be achieved at the higher education system also by the private sector in education as a parallel sector with public systems. Based on NEP-2020, the private sector should give $20 \%$ free seats, $30 \%$ half fee scholarships so that many poor but merit-based students get free or discounted fee study opportunities. Such free education at HE level will boost GER of higher education in the country [74-77].

\section{FURTHER SUGGESTIONS FOR IMPROVEMENTS :}

(1) Ph.D. should be a compulsory qualification for a permanent teaching position in Colleges \& Universities:

Like Integrated B.Ed. is compulsory qualification to Foundation, preparatory, middle, and secondary school education teaching, Ph.D. research should be a compulsory degree for College and University teaching. This is due to the reason that, research is going to be an integral part of bachelor's and master's degrees as per NEP 2020.

\section{(2) Compulsory Faculty Annual Publication leading to IPR :}

In order to maintain sustainable quality and to avoid faculty obsolescence in Colleges and Universities, the IPR generation should be compulsory. In this regard, the college faculties should publish at least two open access scholarly research papers with copyright certificates from Govt. of India or at least two proof of patent submissions annually, failed to which the annual increment should be suspended.

(3) Use of Services of Retired Professors as Research Guides :

The requirement of huge Ph.D. degree holders in autonomous colleges due to changes in policies of NEP 2020 , the demand for research guides is increasing. The optimum solution for solving this shortage is the utilization of services of retired professors with good research experience. It is suggested that the universities should use the services of retired professors as research guides. Thus, retired professors should be used as Research Professors irrespective of their age to guide the research scholars for their Ph.D. Such an idea will eliminate the scarcity of research guides.

(4) A proper definition of Multidisciplinary College :

A multidisciplinary Institution should have a minimum of Five disciplines (not five Courses) belonging to different faculty areas. The real essence of the objective of studying in a Multidisciplinary campus to provide 
multidisciplinary choice and experience of campus comes only if the number of subject disciplines in operations are at least five in number. For example, (1) Languages, (2) Basic Sciences, (3) Social Sciences, (4) Engineering, (5) Education, (6) Medical Sciences, (7) Dental Sciences, (8) Para-medical sciences, (9) Business Management \& Commerce, (10) Computer Science, (11) Agriculture \& Veterinary Science, (12) Law \& Legal Studies, (13) Indian Medicines, (14) Indology, etc.

(5) Higher Education Leaders should be Role Models in Research \& Innovations :

The heads \& members of all Committees of HE Departments and controlling agencies should be selected based on their active research contribution during the last five years. Obsolete deadwood professors/bureaucrats should be kept outside from decision making positions strictly. There should not be any political or bureaucratic interference or appointments to these committees. Age should not be constraints but performance should be criteria. Accordingly, various committees like NHERC, NAC, HEGC, GEC, HECI, NRF, ICAR, VCI, NCTE, CoA, NCVET, etc should have highly qualified and proven researchers who are role models for young generation researchers and active researchers.

(6) Compulsory three modes of Teaching-Learning processes in HEIs :

The HEIs should maximize the use of technology and minimize the brick and mortar model of the campusbased teaching-learning process. To give exposure of online education to tech-generation students the HEIs should adopt technology based training methods which include: (a) Weekly three days classroom-based classes, (b) Weekly 2 days online classes, and (c) Weekly one day industry/vocational/skill based online/classroom-based classes, (d) Two subjects per semester through MOOC like SWAYAM/NPTEL, ODL, etc.

(7) Compulsory Publication/Patent during Postgraduation Courses :

Students are expected to do research based on industry internship and publish scholarly papers / own patents compulsorily as a part of their degree requirement. The awareness related to IPR should be provided during their undergraduate programme so that imposing compulsory copyright/ patent during the postgraduation period is possible. Fixing the target and continuous follow-up through inspiration leads to success.

(8) Universities should have their own Publication Unit :

At HEIs level, the objective of academic research is publication or patent. One of the reasons for reduced research interest in India is the frustration of researchers in the process of scholarly publication or to own a patent is time and expenditure or loss of copyright to so-called international publishers without any financial benefits forever. To avoid such loss to the researchers and to the country, it is suggested all Universities should start their own digital publication units in a systematic way to publish high quality research and sharing with global indexing agencies. Such a university publication model stops predatory journals which follow the illegal or unethical procedure of publication.

(9) Vocational Training based Earn while Learn Encouragement :

To encourage self-dependency after 18 years of age, students should be encouraged to develop skills in their interested area and involve in some kind of economic/productive activities thereby their dependency on parents can be reduced. This is possible through vocational training and building their confidence to earn while learn programmes. The vocational training based earn while learn can be strengthened at HE level through offering additional credits to Academic Bank of Credits (ABC).

(10) Compulsory Employability \& Entrepreneurship related papers in each semester to promote Employability \& Entrepreneurability among the students :

The undergraduate programme should be designed in such a way that there should be two skill based subjects focusing on employability skills and entrepreneurability skills respectively apart from core subjects, non-core subjects, and elective subjects. The evaluation scheme for these skill based subjects should be continuous internal assessment without holding semester end exams. Such an innovative model gives confidence for the students to choose an entrepreneur career.

(11) Faculty Accountability to Boost Performance : API based increments \& Promotion :

According to NEP-2020, both public and Private HEIs are quality focussed and merit based. All faculty and leader's appointments are based on merit based performance and dedication. To maintain sustainability and 
growth in quality, a compulsory assessment based on a tangible scale is essential. Through the Annual Performance Indicator (API) score, Academic performance can be monitored and awareness on academic achievements can be created.

(12) Strict Evaluation of Projects funded by National Research Foundation by creating Research Output Based Credit bank for every NRF members :

Currently, the projects funded by UGC, DST, CSIR, etc are not evaluated in terms of research output and IPR. These outputs should be available publicly as open reports. But it is strongly urged the National Research Foundation (NRF) to watch the output of the research projects it funded and create a National Research Credit Bank (NRCB) of all members of NRF who received funding for their research in the form of an open public document.

(13) Accountability on Output of Research Projects in the form of IPR generated is Important :

In accreditation assessment instead of giving scores for a number of projects received from NRF and other funding agencies, it is important to what is the output of those projects in terms of IPR generation.

(14) Promotion to Open Access Publications with retention of Copyright with authors :

Promotion of Indian Journals which are not for profit and run by Universities to avoid huge money flow (both for journal subscriptions or as article processing charges) to other countries. National Research Foundation should encourage to get copyright of published research articles through the Copyright Office of Govt. of India. Researchers of all HEIs should be encouraged to compulsorily apply for the copyright of their publications with the Copyright Office of Govt. of India like patent registration.

(15) Simplification patent filing and speedup of Patent Evaluation :

Indian Government, through arranging awareness programmes, researchers are made familiar to patent filing procedures and the patent filing fees and evaluation fees with the time of evaluation should be decreased to 3 to 6 months instead current 3 to 6 years. This will encourage innovators to file for patents for their inventions.

(16) Removal of Obsolesce in Higher Education System :

Based on strict policies and accountability measures, all non-performers and obsolete human resources working in the Higher Education system, maybe in colleges, universities, or HE regulatory systems should be removed from time to time. For example, people who fail to produce at least 10 IPRs in their name during a period of 5 years should be retired compulsorily from their positions and excluded from any membership or leadership positions of HE regulatory committees.

(17) Strengthening Integrated National Digital Library (INDL):

National Digital Library should be strengthened to adding every book published in the country through strict instructions to the National ISBN granting agency and a digital copy of all Journals which have ISSN. Library grants to all other libraries of any sectors should be stopped and their libraries should be converted into Digital libraries through the membership of the Integrated National Digital Library. All HEIs should be the compulsory member of the INDL to have access to books, periodicals, Journals, Patents, and every other database from a single place. With this model, multiple subscriptions of library resources can be eliminated. This will decrease Government expenditure on Library resources and eliminates huge amounts of money from foreign exchange.

\section{CONCLUSION :}

Higher education is an important aspect in deciding the economy, social status, technology adoption, and healthy human behaviour in every country. Improving GER to include every citizen of the country in higher education offerings is the responsibility of the education department of the country government. National Education Policy of India 2020 is marching towards achieving such objective by making innovative policies to improve the quality, attractiveness, affordability, and increasing the supply by opening up the higher education for the private sector and at the same time with strict controls to maintain quality in every higher education institution. By encouraging merit-based admissions with free-ships\& scholarships, merit \& research based continuous performers as faculty members, and merit based proven leaders in regulating 
bodies, and strict monitoring of quality through biennial accreditation based on self-declaration of progress through technology-based monitoring, NEP-2020 is expected to fulfill its objectives by 2030. All higher education institutions with current nomenclature of affiliated colleges will expand as multi-disciplinary autonomous colleges with degree giving power in their name or becomes constituent colleges of their affiliated universities. An impartial agency National Research Foundation will fund for innovative projects in priority research areas of basic sciences, applied sciences, and social sciences \& humanities. HE system will transform itself as student centric with the freedom to choose core and allied subjects within a discipline and across disciplines. Faculty members also get autonomy to choose curriculum, methodology, pedagogy and evaluation models within the given policy framework. These transformations will start from the academic year 2021-22 and will continue until the year 2030 where the first level of transformation is expected to visible. Hence, the Indian higher education system is moving from teacher centric to student centric, information centric to knowledge centric, marks centric to skills centric, examination centric to experimental centric, learning centric to research centric, and choice centric to competency centric.

\section{REFERENCES :}

[1] Kumar, K. (2005). Quality of Education at the Beginning of the 21st Century: Lessons from India. Indian Educational Review, 40(1), 3-28.

[2]Draft National Education Policy 2019, $\underline{\text { https://innovate.mygov.in/wp- }}$ content/uploads/2019/06/mygov15596510111.pdf

[3] Aithal, P. S. \& Aithal, Shubhrajyotsna (2019). Analysis of Higher Education in Indian National Education Policy Proposal 2019 and its Implementation Challenges. International Journal of Applied Engineering and Management Letters (IJAEML), 3(2), 1-35. DOI: http://doi.org/10.5281/Zenodo.3271330.

[4] National Education Policy 2020. https://www.mhrd.gov.in/sites/upload_files/mhrd/files/nep/ NEP Final_English.pdf referred on 10/08/2020.

[5] Onwuegbuzie, A. J., Dickinson, W. B., Leech, N. L., \& Zoran, A. G. (2009). A qualitative framework for collecting and analyzing data in focus group research. International journal of qualitative methods, 8(3), 121.

[6] Aithal, P. S., (2016). Study on ABCD Analysis Technique for Business Models, business strategies, Operating Concepts \& Business Systems, International Journal in Management and Social Science, 4(1), 98115. DOI : http://doi.org/10.5281/zenodo.161137.

[7] Shubhrajyotsna Aithal \& Aithal, P. S. (2018). The Realization Opportunity of Ideal Energy System using Nanotechnology Based Research and Innovations. International Journal of Advanced Trends in Engineering and Technology, 3(2), 1-15. DOI : http://doi.org/10.5281/zenodo.2531876.

[8] Aithal, P. S. \& Shubhrajyotsna Aithal (2019). Building World-Class Universities : Some Insights \& Predictions. International Journal of Management, Technology, and Social Sciences (IJMTS), 4(2), 13-35. DOI:http://doi.org/10.5281/zenodo.3377097.

[9] Aithal, P. S. (2016). Student Centric Curriculum Design and Implementation - Challenges \& Opportunities in Business Management \& IT Education. IRA International Journal of Education and Multidisciplinary Studies, 4(3), 423-437. DOI : http://dx.doi.org/10.21013/jems.v4.n3.p9.

[10] Simão, A. M. V., \& Flores, M. A. (2010). Student-centred methods in higher education: Implications for student learning and professional development. The International Journal of Learning, 17(2), 207-218.

[11] Shubrajyotsna Aithal \& Aithal, P. S., (2016). Student Centric Learning Through Planned Hardwork An Innovative Model. International Journal of Scientific Research and Modern Education (IJSRME), 1(1), 886-898. DOI: http://doi.org/10.5281/zenodo.61830. 
[12] Aithal P. S. \& Aithal Shubhrajyotsna (2020). Promoting Faculty and Student-Centered Research and Innovation based Excellence Model to Reimage Universities. International Journal of Management, Technology, and Social Sciences (IJMTS), 5(1), 24-41. DOI: http://doi.org/10.5281/zenodo.3702399.

[13] Aithal, P. S. (2016). Innovations in Student Centric Learning - A Study of Top Business Schools in India. International Journal of Engineering Research and Modern Education (IJERME), 1(1), 298-306. DOI :http://doi.org/10.5281/zenodo.161045.

[14] Aithal P. S., \& Suresh Kumar P. M. (2018). Approaches to Confidence Building as a Primary Objective in Postgraduate Degree Programmes.International Journal of Applied Engineering and Management Letters (IJAEML), 2(1), 64-71. DOI: http://dx.doi.org/10.5281/zenodo.1205185.

[15] Aithal, P. S. (2016). Creating Innovators through setting up organizational Vision, Mission and Core Values : a Strategic Model in Higher Education. International Journal of Management, IT and Engineering (IJMIE), 6(1), 310-324. DOI : http://doi.org/10.5281/zenodo.161147.

[16] Pradeep M.D, and Aithal, P. S., (2015). Learning through Team Centric Exercise \& Key Point Pedagogy - An effective Learning Model for Slow Learners in Higher Education Training, International Journal of Multidisciplinary Research \& Development, 2(9), 265-270. DOI: http://doi.org/10.5281/zenodo.267765.

[17] Aithal, P. S., P. M. Suresh Kumar and Deekshitha, (2015). Societal Expectation and Institutional Accountability in Higher Education.International Journal of Management, IT and Engineering (IJMIE), 5(7), 361-373. DOI : http://doi.org/10.5281/zenodo.267021.

[18] Aithal, P. S., Suresh Kumar, P. M., and Pavithra Kumari, (2015). Methods and Approaches for Employability Skill Generation in Higher Educational Institutions.International Journal of Management, IT and Engineering (IJMIE), 5(7), 390-410. DOI: http://doi.org/10.5281/zenodo.267044.

[19] Desai, M. S., \& Johnson, R. A. (2014). Integrated systems-oriented student-centric learning environment. Campus-Wide Information Systems. 31(1), 24-45.

[20] Kealey, D. J., Protheroe, D. R., MacDonald, D., \& Vulpe, T. (2003). Instituting a competency-based training design and evaluation system. Performance Improvement, 42(5), 28-33.

[21] Suresh Kumar P. M \& Aithal P. S. (2019). Competency Assessment and Grading in Higher Education. Scholedge International Journal of Multidisciplinary \& Allied Studies, 6(12), 127-136. DOI: http://doi.org/10.5281/Zenodo.3648182.

[22] Aithal, P. S. \& Suresh Kumar, P.M. (2016). Analysis of Choice Based Credit System in Higher Education. International Journal of Engineering Research and Modern Education (IJERME), 1(1), 278-284. DOI: http://doi.org/10.5281/zenodo.161046.

[23] Aithal, P. S. \&Suresh Kumar, P. M. (2016). Student Evaluation and Reforms in Higher Education Institutions. International Journal of Multidisciplinary Research and Modern Education (IJMRME), 2(1), 652-661. DOI: http://doi.org/10.5281/zenodo.160932.

[24] Aithal P. S. \& Suresh Kumar P. M. (2018). Approaches to Confidence Building as a Primary Objective in Postgraduate Degree Programmes. International Journal of Applied Engineering and Management Letters (IJAEML), 2(1), 64-71. DOI: http://dx.doi.org/10.5281/zenodo.1205185.

[25] Dauphinee, W. D., Boulet, J. R., \& Norcini, J. J. (2019). Considerations that will determine if competency-based assessment is a sustainable innovation. Advances in Health Sciences Education, 24(2), 413-421.

[26] Mohrman, K., Ma, W., \& Baker, D. (2008). The research university in transition: The emerging global model. Higher education policy, 21(1), 5-27. 
[27] Prathap, G. (2014). The performance of research-intensive higher educational institutions in India. Current Science, 389-396.

[28] Aithal, P. S. \& Suresh Kumar, P.M., (2016). ABC Model of Research Productivity and Higher Educational Institutional Ranking. International Journal of Education and Management Engineering (IJEME), 6(6), 74-84. DOI: http://doi.org/10.5815/ijeme.2016.06.08.

[29] Aithal, P. S. (2016). Research Performance Analysis of Some Indian Top Business Schools Using ABC Model. International Journal of Computational Research and Development, 1(1), 70-83. DOI : http://doi.org/10.5281/zenodo.163532.

[30] Aithal, P. S. \& Shubhrajyotsna Aithal (2019). Transforming Society by Creating Innovators through Skill \& Research Focussed Education - A Case Study of Srinivas University. International Journal of Applied Engineering and Management Letters (IJAEML), 3(1), 17-37. DOI: http://doi.org/10.5281/zenodo.2653045.

[31] Aithal, P. S. \& Suresh Kumar, P. M. (2017). Challenges and Opportunities for Research \& Publications in Higher Education. International Journal of Scientific Research and Modern Education (IJSRME), 2(1), 42-49. DOI: http://dx.doi.org/10.5281/zenodo.400619.

[32] Bouhajeb, M., Mefteh, H., \& Ammar, R. B. (2018). Higher education and economic growth: the importance of innovation. Atlantic Review of Economics, 1(2), 4.

[33] Fan, S. C., \& Yu, K. C. (2017). How an integrative STEM curriculum can benefit students in engineering design practices. International Journal of Technology and Design Education, 27(1), 107-129.

[34] Aithal, P. S., \& Aithal, Shubhrajyotsna. (2019). Innovation in B.Tech. Curriculum as B.Tech. (Hons) by integrating STEAM, ESEP \& IPR features. International Journal of Case Studies in Business, IT, and Education (IJCSBE), 3(1), 56-71. DOI: http://doi.org/10.5281/zenodo.3248630.

[35] Aithal, P. S. (2016). Innovations in Experimental Learning - A Study of World Top Business Schools. International Journal of Scientific Research and Modern Education (IJSRME), 1(1), 360-375. DOI : http://doi.org/10.5281/zenodo.161043.

[36] Aithal, P. S., Suresh Kumar, P. M., and Pavithra Kumari, (2015). Methods and Approaches for Employability Skill Generation in Higher Educational Institutions.International Journal of Management, IT and Engineering (IJMIE), 5(7), 390-410. DOI: http://doi.org/10.5281/zenodo.267044.

[37] Aithal P. S. \& Shubhrajyotsna Aithal (July 2020). Importance of Arts \& Design in Liberal education STEAM model of Higher Education. Chapter I, pp. 1-24. Applied Arts Science in IT Age, Edited by Dr. P. K. Paul, New Delhi Publishers, New Delhi, India. ISBN: 978-93-88879-90-3.

[38] Kim, S. W., Chung, Y. L., Woo, A. J., \& Lee, H. J. (2012). Development of a theoretical model for STEAM education. Journal of the Korean Association for Science Education, 32(2), 388-401.

[39] Stohlmann, M. (2018). A vision for future work to focus on the "M" in integrated STEM. School Science and Mathematics, 118(7), 310-319.

[40] Aithal, P. S. (2018). How to Boost Faculty Research Performance in HEI's to Improve Intellectual Property by Integrating it with Faculty Compensation - A "Theory of Accountability" based Framework. International Journal of Management, Technology, and Social Sciences (IJMTS),3(2), 130-151. DOI: https://doi.org/10.5281/zenodo.1689055.

[41] Aithal, P. S. \& Suresh Kumar P. M. (2017). Interconnecting Theory A and ABC Model of Organizational Performance. International Journal of Management, Technology and Social Sciences (IJMTS), 1(1), 1-13. DOI: http://dx.doi.org/10.5281/zenodo.268598.

[42] Aithal, P. S. (2016). Study of Annual Research Productivity in Indian Top Business 
Schools. International Journal of Scientific Research and Modern Education (IJSRME), 1(1), 402-414. DOI : http://doi.org/10.5281/zenodo.161041.

[43] Aithal, P. S. (2016). How to Increase Research Productivity in Higher Educational Institutions -SIMS Model, International Journal of Scientific Research and Modern Education (IJSRME), 1(1), 447-458. DOI : http://doi.org/10.5281/zenodo.161037.

[44] Aithal, P. S. (2016). Study of Research Productivity in World Top Business Schools. International Journal of Engineering Research and Modern Education (IJERME), 1(1), 629-644. DOI: http://doi.org/10.5281/zenodo.160969.

[45] Aithal, P. S. \& P. M. Suresh Kumar, (2016). Maintaining Teacher Quality in Higher Education Institutions, International Journal of Current Research and Modern Education (IJCRME), 1(1), 701-711. DOI : http://doi.org/10.5281/zenodo.1 60946.

[46] Aithal, P. S. and P. M. Suresh Kumar (2016). Organizational Behaviour in $21^{\text {st }}$ Century - Theory A for Managing People for Performance. IOSR Journal of Business and Management (IOSR-JBM), 18, 7, 126-134. DOI: http://doi.org/10.9790/487X-180704126134.

[47] Aithal, P. S. \& Suresh Kumar, P. M. (2016). Application of Theory A on ABC Model to enhance Organizational Research Productivity in Higher Education. International Journal of Advanced Trends in Engineering and Technology (IJATET), 1(1), 142-150. DOI : http://doi.org/10.5281/zenodo.240646.

[48] Aithal, P. S., Shailashree V. T\& Suresh Kumar P. M., (2016). Analysis of ABC Model of Annual Research Productivity using ABCD Framework. International Journal of Current Research and Modern Education (IJCRME), 1(1), 846-858. DOI: http://doi.org/10.5281/zenodo.62022.

[49] Benjamin, E. (1994). From accreditation to regulation: The decline of academic autonomy in higher education. Academe, 80(4), 34-36.

[50] Aithal, P. S. \& Shubhrajyotsna Aithal (September 2019). Autonomy for Universities Excellence Challenges and Opportunities. International Journal of Applied Engineering and Management Letters (IJAEML), 3(2), 36-50. DOI: http://doi.org/10.5281/zenodo.3464710.

[51] Aithal P. S. \& Suresh Kumar P. M. (November 2019). Autonomy in Higher Education - Towards an Accountability Management Model. International Journal of Management \& Development, 6(10), 166-175. ISSN 2394-3378. DOI : https://doi.org/10.5281/zenodo.3594255.

[52] Sankaran, K., \& Joshi, G. V. (2016). Autonomy for excellence in higher education in India. Nitte Management Review, 10(2), 1-10.

[53] Sabic-El-Rayess, A. (2016). Merit matters: Student perceptions of faculty quality and reward. International Journal of Educational Development, 47, 1-19.

[54] Aithal, P. S. \& Suresh Kumar, P. M. (2016). Catering Student Enrollment and Retaining Diversity in Higher Education Institutions, International Journal of Engineering Research and Modern Education (IJERME), 1(1), 565 - 577. DOI : http://doi.org/10.5281/zenodo.160939.

[55] Aithal, P. S. (2015). Strategies to be adopted in Higher Education Institutions to Enhance Admission Demand. International Journal of Extensive Research, 5(1), 9-25, DOI: http://doi.org/10.5281/zenodo.268530.

[56] Nyden, P. (2003). Academic incentives for faculty participation in community-based participatory research. Journal of General Internal Medicine, 18(7), 576-585.

[57] Aithal P. S. (2018). Effect of Role Models - A Critical Study on the Recent Research Contribution of Vice-Chancellors of Selected Private Universities in India. International Journal of Management, 
Technology, and Social Sciences (IJMTS), 3(1), 118-139. DOI : http://doi.org/10.5281/zenodo.1257729.

[58] Aithal, P. S., (2016). Inspiring through Self-Contribution - An Analysis of How Active the Indian Top Business School Directors in Research \& Publications. International Journal of Engineering Research and Modern Education (IJERME),1(2), 137 - 154. DOI: http://dx.doi.org/10.5281/zenodo.164690.

[59] Aithal, P. S., (2016). Excellence in Individual Research \& Publications : Examining the Active Role of Role models (Deans) of World Top Business Schools. International Journal of Engineering Research and Modern Education (IJERME), 1(2), 179-199. DOI: http://dx.doi.org/10.5281/zenodo.192881.

[60] Aithal, P. S. (2015). How an Effective Leadership and Governance Supports to Achieve Institutional Vision, Mission, and Objectives. International Journal of Multidisciplinary Research and Development, 2(5), 154-161. DOI: http://doi.org/10.5281/zenodo.266788.

[61] Speizer, J. J. (1981). Role models, mentors, and sponsors: The elusive concepts. Signs: Journal of Women in Culture and Society, 6(4), 692-712.

[62] Aithal, P. S., \& Shubhrajyotsna Aithal, (2015). An Innovative Education Model to realize Ideal Education System. International Journal of Scientific Research and Management (IJSRM), 3(3), 2464 - 2469 , DOI: http://doi.org/10.5281/zenodo.61654.

[63] Aithal, P. S. \& Shubhrajyotsna Aithal, (2016). Impact of On-line Education on Higher Education System, International Journal of Engineering Research and Modern Education (IJERME), 1(1), 225-235. DOI : http://doi.org/10.5281/zenodo.161113.

[64] Suresh Kumar, P. M. \& Aithal, P. S. (2016). Working from Home - A Transition in the concept of Workplace. International Journal of Current Research and Modern Education (IJCRME), 1(1), 244-249. DOI : http://doi.org/10.5281/zenodo.161110.

[65] Aithal, P. S. \& Shubhrajyotsna Aithal, (June 2020). Conceptual Analysis on Higher Education Strategies for various Tech-Generations. International Journal of Management, Technology, and Social Sciences (IJMTS), 5(1), 335-351. DOI: http://doi.org/10.5281/zenodo.3940590.

[66] Aithal, P. S. \& Madhushree, L. M. (2019). Information Communication \& Computation Technology (ICCT) as a Strategic Tool for Industry Sectors. International Journal of Applied Engineering and Management Letters (IJAEML), 3(2), 65-80. DOI: http://doi.org/10.5281/zenodo.3549423.

[67] Madhushree, L. M., Radhakrishnan, R., \& Aithal, P. S. (2019). A Review on Impact of Information Communication \& Computation Technology (ICCT) on Selected Primary, Secondary, and Tertiary Industrial Sectors. Saudi Journal of Business and Management Studies, 4(1), 106-127.

[68] Ossiannilsson, E., Altinay, F., \& Altinay, Z. (2016). MOOCs as change agents to boost innovation in higher education learning arenas. Education Sciences, 6(3), 25-30.

[69] Devi, S., Rizwaan, M., \& Chander, S. (2012). ICT for Quality of Education in India. International Journal of Physical and Social Sciences, 2(6), 542-554.

[70] Sinha, V., \& Subramanian, K. S. (2013). Accreditation in India: path of achieving educational excellence. Business education \& accreditation, 5(2), 107-116.

[71] Aithal, P. S., Shailashree, V. T. \& Suresh Kumar, P. M. (2016). Analysis of NAAC Accreditation System using ABCD framework. International Journal of Management, IT and Engineering (IJMIE), 6(1), 30 - 44. DOI : http://doi.org/10.5281/zenodo.154272.

[72] Ulker, N., \& Bakioglu, A. (2019). An international research on the influence of accreditation on academic quality. Studies in Higher Education, 44(9), 1507-1518.

[73] Harvey, L. (2004). The power of accreditation: Views of academics. Journal of Higher Education Policy 
and Management, 26(2), 207-223.

[74] Costanza, R., Fioramonti, L., \& Kubiszewski, I. (2016). The UN sustainable development goals and the dynamics of well-being. Frontiers in Ecology and the Environment, 14(2), 59-59.

[75] Aithal, P. S. \& P.M. Suresh Kumar, (2016). Innovations in Private Universities : A Case of Srinivas University. International Journal of Management, IT and Engineering (IJMIE), 6(1), 250-264. DOI : http://doi.org/10.5281/zenodo.161151.

[76] Aithal, P. S. \& Suresh Kumar, P.M. (2016). Opportunities and Challenges for Private Universities in India. International Journal of Management, IT and Engineering (IJMIE), 6(1), 88-113. DOI : http://doi.org/10.5281/zenodo.161157.

[77] Singh, J. D. (2011). Higher education in India-Issues, challenges and suggestions. Higher education, 93-103, ISBN: 978-3-8465-1753-6. 